\title{
Study of acute hepatotoxicity of Equisetum arvense $L$. in rats $^{1}$
}

\author{
Estudo da hepatotoxicidade aguda da Equisetum arvense L. em ratos
}

\author{
Nilo César do Vale BarachoI, Bruno Battiston Vilela VicenteII, Guilherme D’Andréa Saba Arruda", Brunno Cezar Framil Sanches", \\ Jarbas de Brito ${ }^{\mathrm{III}}$ \\ ${ }^{\text {I }}$ Master, Associate Professor, Pharmacology and Biochemistry, Itajubá School of Medicine, Minas Gerais, Brazil.

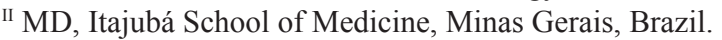

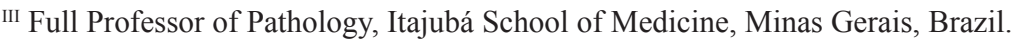

\begin{abstract}
Purpose: To evaluate the acute hepatotoxicity of Equisentum arvense L. in rats. Methods: Fifty Wistar rats were used, these being divided in four groups, one being the control (receiving only water) and the other groups receiving graded doses of Equisentum arvense L. (30, 50, and $100 \mathrm{mg} / \mathrm{kg}$ respectively) for 14 days. Blood samples were obtained to determine TGO, TGP, FA, DHL and GT-gamma activities. After that, hepatic tissue samples were collected for the anatomopathologic analysis. Results: The anatomopathologic exam of the hepatic tissue showed organ with preserved lobular structure. In the same way, there was no significant change in the seric activities of the hepatic enzymes when compared to control group. Conclusion: The oral treatment with graded doses of Equisentum arvense L. was not able to produce hepatic changes. Further studies are necessary to evaluate the chronic hepatotoxicity of Equisentum arvense L. in rats.
\end{abstract}

Key words: Equisentum arvense. Acute Toxicity. Liver. Rats.

\section{RESUMO}

Objetivo: Investigar a hepatotoxicidade aguda da Equisetum arvense L. em ratos. Métodos: foram utilizados 50 ratos Wistar, os quais foram divididos em quatro grupos, sendo um controle (recebendo apenas água) e os outros grupos recebendo doses crescentes de cavalinha $(30,50$ e $100 \mathrm{mg} / \mathrm{Kg}$, respectivamente) por 14 dias. Foram coletadas amostras de sangue para determinação da atividade sérica de TGO, TGP, FA, DHL e gama-GT. Em seguida, foram obtidas amostras de tecido hepático para análise anatomopatológica. Resultados: O exame anatomopatológico de tecido hepático demonstrou órgão com estrutura lobular preservada. Da mesma forma, não houve alteração significativa na atividade sérica das enzimas hepáticas, quando comparado ao grupo controle. Conclusão: O tratamento com doses crescentes de Equisetum arvense L., não induziu hepatotoxicidade aguda em ratos. Novos estudos são necessários para avaliar a hepatoxicidade crônica de Equisetum arvense L. em ratos.

Descritores: Equisetum arvense. Toxicidade Aguda. Fígado. Ratos.

${ }^{1}$ Research performed at the Biochemistry, Pharmacology and Pathologic Anatomy laboratories, Itajubá School of Medicine, Minas Gerais, Brazil.

\section{Introduction}

The liver plays a central role in many physiologic processes such as: albumin production and many other plasmatic proteins; seric glucose synthesis; plasmatic lipoprotein synthesis; elimination of toxic substances and inactivation of many medicaments; formation of the gall; stock of vitamins and iron; formation of coagulation factors ${ }^{1}$. The hepatic dysfunction caused by conventional drugs represents between 2 and $5 \%$ of the cases of jaundice of hospitalized patients, $10 \%$ of acute hepatitis in the adult and more than $40 \%$ in the people over 50 years of age. It represents around $25 \%$ of the causes of fulminate hepatic failure in the adult ${ }^{2-5}$. Other drugs that may cause hepatic damage are the phytotherapics ${ }^{6}$. These medicinal plants are a therapeutic alternative which has been used by mankind for many years and it is being used more and more by the patients. However, these drugs need further study so that they can be used with more security ${ }^{6}$. Among these phytotherapics is the Equisetum arvense L., "Cavalinha", a plant originated from Europe which was been widely used by the general population as a diuretic agent and it is indicated in many pathologies, such as fracture recalcification processes, maintenance of the arterial resilience, decrease of the plasmatic cholesterol LDL levels, a helper in the treatment of high blood pressure, edemas and diets to lose weight ${ }^{7}$. Nevertheless, there is no knowledge of its action mechanism and its possible side effects and there are divergences in the medical literature regarding its possible hepatotoxicity ${ }^{7-9}$.

In this context, the present study aimed to evaluate the chronic effect of oral administration of graded doses of Equisetum arvense $(L)$ on hepatic enzymes seric activities and hepatic histology in rats. 


\section{Methods}

The study was approved for Ethics Committee of Itajubá School of Medicine and followed the recommendations of COBEA (Brazilian Animal Experimentation Committee) and according to the rules of Federal Law number 6638 and of the CIOMS (Council for International Organization of Medical Science).

Fifty adults male Wistar rats weighing between 220 to $300 \mathrm{~g}$ were housed in a controlled environment in our animal facility. Animals were randomized into the following groups: rats receiving distilled water (control group, $\mathrm{n}=10$ ), and animals receiving graded doses of Equisetum arvense (L): $30 \mathrm{mg} / \mathrm{Kg}$ (group 1, $\mathrm{n}=10$ ), 50 $\mathrm{mg} / \mathrm{Kg}$ (group 2, $\mathrm{n}=10$ ), and $100 \mathrm{mg} / \mathrm{Kg}$ (group 3, $\mathrm{n}=10$ ).

The rats were placed in individual plastic cages. After the adaptative period of three days, the following treatments were daily administrated by gavage during two weeks: distilled water (control), graded doses of Equisetum arvense (L). At the end of the experiment (day 14), animals were anesthetized (ketamin $50 \mathrm{mg} / \mathrm{Kg}$ plus xylazin $25 \mathrm{mg} / \mathrm{Kg}$, I.P) and blood samples were collected by heart puncture to determine hepatic enzymes seric activities. Blood samples were centrifuged at $2500 \mathrm{rpm}$ for 10 minutes and the serum was stored at $-4^{\circ} \mathrm{C}$. Hepatic tissue fragments were also obtained for histological analysis.

\section{Plant material}

Equisetum arvense ( $L$ ) extract was provided by BIONATUS laboratory. The material was shade-dried and powdered.

\section{Extraction}

The dried powdered plant material $480 \mathrm{mg}$ was diluted with $10 \mathrm{ml}$ of distilled water achieving a final concentration of 48 $\mathrm{mg} / \mathrm{ml}$. The solution was kept under refrigeration and renewed at each 2 days. Phytochemical studies show that Equisetum arvense $L$. extract possesss phenolic and flavonoids compounds ${ }^{8,9}$.

\section{Biochemical parameters}

To determine the seric activities of Aspartate Amino Transferase (AST) and Alanine Amino Transferase (ALT), it was used the colorimetric method, Reitman-Frankel. For the seric activity determination of Gamma Glutamil Transferase $(\cdot \gamma-\mathrm{GT})$, it was used the kinetic-colorimetric method, and for the dosage of the Alkaline Phosphatase (ALP) it was used the photo colorimetric method, Modified Roy (LabTest, Minas Gerais, Brazil).

\section{Histological analysis}

Five-micrometer sections of formalin-fixed and paraffin-embedded liver slices were processed routinely with hematoxylin-eosin A single pathologist, blinded to experimental protocol, analyzed all livers fragments using light microscopy.

\section{Statistical analysis}

Gaussian distribution of variables was evaluated by the Shapiro normality test. Results were reported as mean \pm standard error of mean (SEM) or median when appropriate. Student $t$ test was used for the comparison of means between groups. Kruskal-Wallis, followed by the Dunn test, were used to compare non-parametric data. The level of significance was set at $\mathrm{p}<0.05$ and the Software Statistica was used for the statistical analyses $^{10}$.

\section{Results}

Concerning acute toxicity, there was no mortality in any of the above-mentioned doses at the end of the 14 days of observation. The treatment with graded doses of Equisetum arvense $(L)$, did not change serum activities of hepatic enzymes in comparison to control group (Table 1).

TABLE1 - Effects of treatment with Control or graded doses of Equisetum arvense $L$. in the hepatic enzymes (AST, ALT, $\gamma$-GT and ALP), $p>0,05$

\begin{tabular}{c|c|c|c|c|c}
\hline GROUP & AST & ALT & $\gamma$-GT & ALP & SAMPLE \\
& $\mathbf{( U / m L )}$ & $\mathbf{( U / m L )}$ & $\mathbf{( U / m L )}$ & $\mathbf{( U / L )}$ & (n) \\
\hline Control & $148,7 \pm 99,1$ & $55,2 \pm 29,9$ & $19,0 \pm 9,6$ & $188,2 \pm 63,2$ & 10 \\
\hline E. arvense L 30mg/kg & $148,3 \pm 129,9$ & $55,2 \pm 25,3$ & $25,4 \pm 29,1$ & $132,2 \pm 42,8$ & 10 \\
\hline E. arvense L 50mg/kg & $91,90 \pm 40,7$ & $39,0 \pm 13,9$ & $22,2 \pm 11,7$ & $185,7 \pm 72,7$ & 10 \\
\hline E. arvense L 100mg/kg & $171,9 \pm 137,3$ & $67,2 \pm 43,8$ & $19,1 \pm 15,9$ & $183,5 \pm 54,7$ & 10 \\
\hline Hydrochlorothiazide & $151,40 \pm 76,4$ & $56,6 \pm 32,8$ & $19,0 \pm 8,3$ & $164,7 \pm 82,4$ & 10 \\
\hline $\mathbf{1 0} \mathbf{~ m g / k g}$ & & & & & \\
\hline
\end{tabular}


In addition, the administration of 30,50 and $100 \mathrm{mg} / \mathrm{Kg}$ produced only benign changes in the hepatic morphology of Equisetum arvense L. or destilled water (control group) (Table 2 and Figures 1, 2 and 3).

TABLE 2 - Effects of treatment with Control or graded doses of Equisetum arvense L. in the hepatic morphology

\begin{tabular}{|c|c|c|}
\hline Group & Anatomopathologic Findings & Animals \\
\hline Control & $\begin{array}{c}\text { Preserved centrolobular structure } \\
\text { Centrolobular steatosis }\end{array}$ & $\begin{array}{l}4 \\
6\end{array}$ \\
\hline $\begin{array}{l}\text { Equisetum arvense } L . \\
\qquad 30 \mathrm{mg} / \mathrm{Kg}\end{array}$ & $\begin{array}{c}\text { Preserved centrolobular structure } \\
\text { Centrolobular steatosis } \\
\text { Cellular tumefaction (Hydropic degeneration) }\end{array}$ & $\begin{array}{l}2 \\
2\end{array}$ \\
\hline $\begin{array}{c}\text { Equisetum arvense } L . \\
50 \mathrm{mg} / \mathrm{Kg}\end{array}$ & $\begin{array}{c}\text { Preserved centrolobular structure } \\
\text { Cellular tumefaction (Hydropic degeneration) } \\
\text { Centrolobular steatosis }\end{array}$ & $\begin{array}{l}3 \\
4\end{array}$ \\
\hline $\begin{array}{c}\text { Equisetum arvense L. } \\
100 \mathrm{mg} / \mathrm{Kg}\end{array}$ & $\begin{array}{c}\text { Preserved centrolobular structure } \\
\text { Centrolobular steatosis } \\
\text { Cellular tumefaction (Hydropic degeneration) }\end{array}$ & $\begin{array}{l}3 \\
2\end{array}$ \\
\hline
\end{tabular}

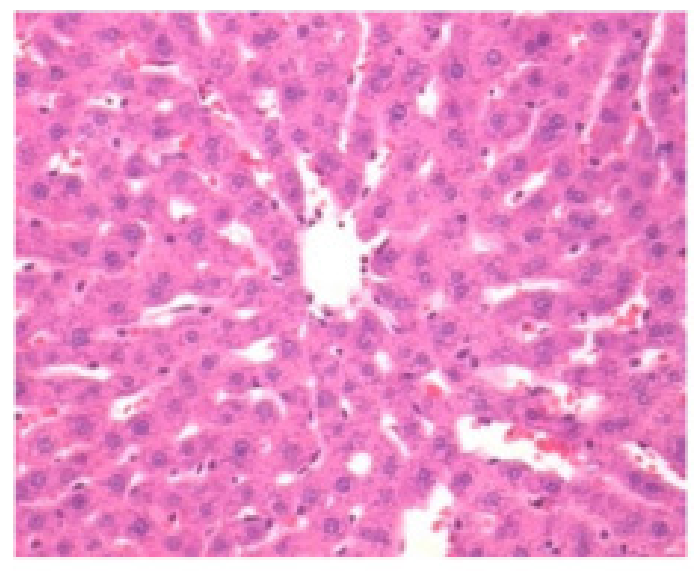

A

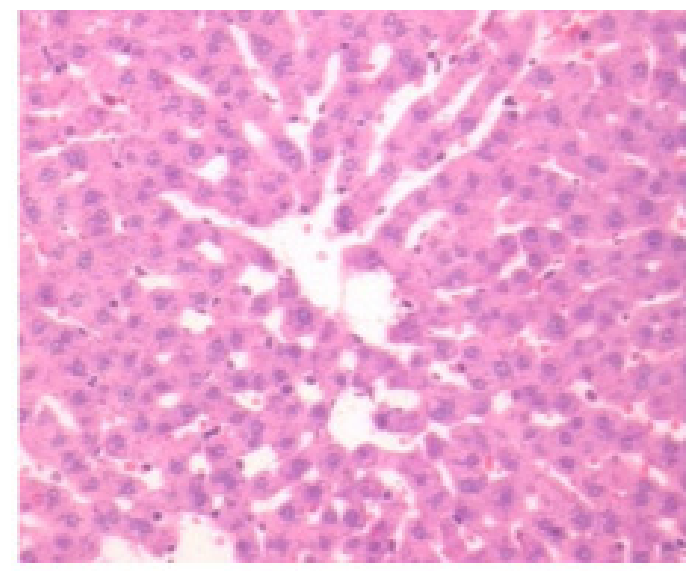

B

FIGURE 1 - A. Hepatic micrograph of control group. B. Hepatic micrograph of group treated with $30 \mathrm{mg} / \mathrm{Kg}$ of Equisetum arvense L. 


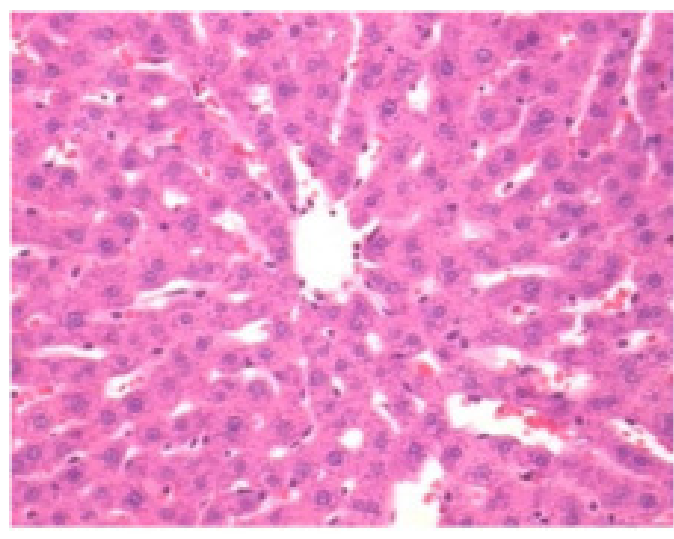

A

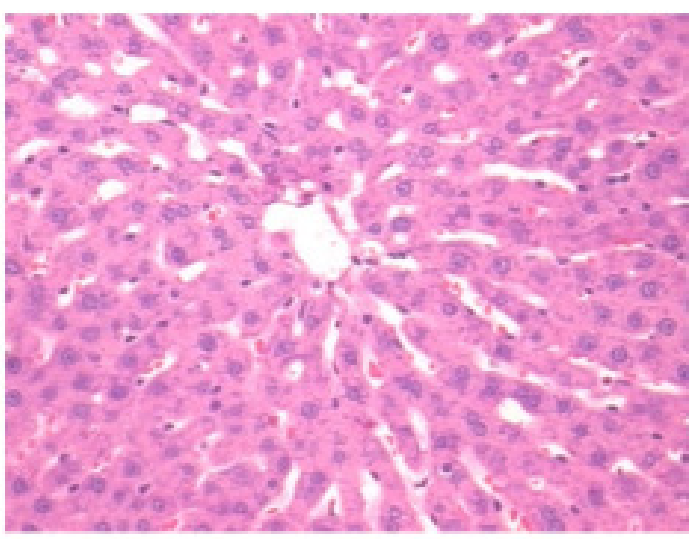

B

FIGURE 2 - A. Hepatic micrograph of control group. B. Hepatic micrograph of group treated with 50mg/Kg of Equisetum arvense L.

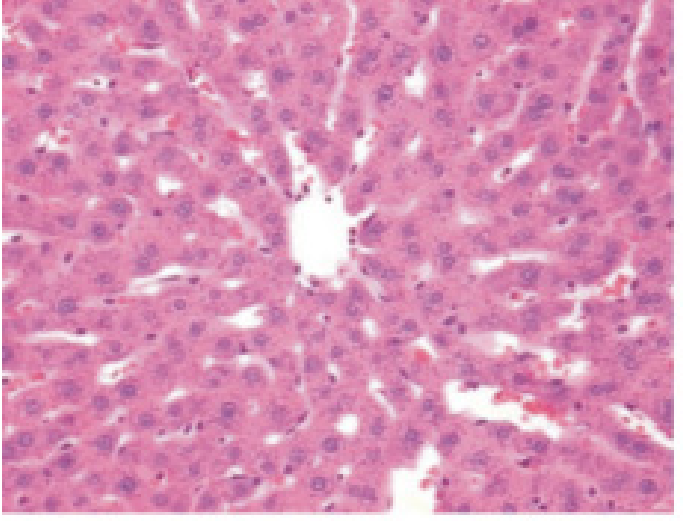

A

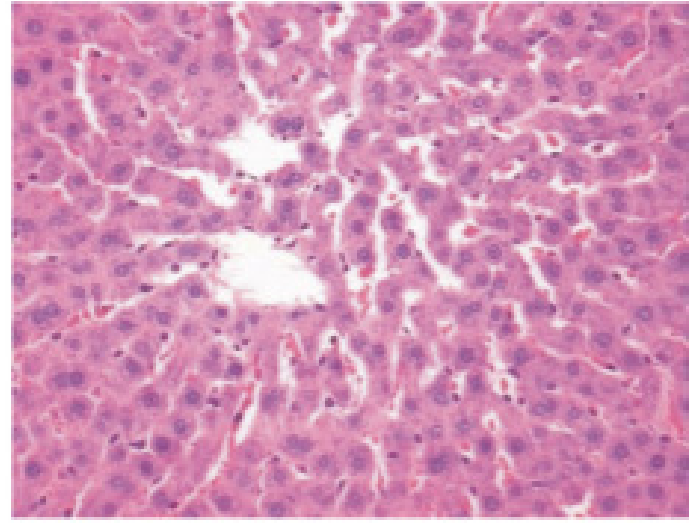

B

FIGURE 3 - A. Hepatic micrograph of control group. B. Hepatic micrograph of group treated with $100 \mathrm{mg} / \mathrm{Kg}$ of Equisetum arvense L.

\section{Discussion}

Among the medicinal plants, some are responsible for causing hepatic morphologic changes which is the case of Croton cajucara benth, knowned by the people as "Sacaca", which can cause severe cholestatic acute hepatitis. Another known case is the Heliotropium senecio, which can cause fulminate acute hepatitis when used in high doses ${ }^{11,12}$.

In this context, our results shown that the treatment with Equisetum arvense $L$. in graded doses $(30,50$ and $100 \mathrm{mg} / \mathrm{Kg}$ ) for 14 days did not produce important changes in the morphology and hepatic function in rats. The little hepatic morphology changes found in the Equisetum arvense L. groups are considered benign form and should not be attributed to use of the extract of Equisetum arvense $L$.

For the other hand, the control group were not submitted to any treatment. This way, the anatomopathologic results found in the hepatic tissue of these animals are probably due to the inherent conditions of their metabolisms.

Recent studies indicates that Equisetum arvense $L$. presents hepatoprotec tive effect in rats and its effects can be attributed to the flavonoids and phenolic compounds ${ }^{8,9}$.

For the other hand, Semprini et al. ${ }^{7}$ showed that the oral administration of Equisetum arvense L. in Wistar rats for seven days produced important changes in the hepatic structure such as decrease in the number of hepatocytes, increase in the cytoplasmic volume and production of the nuclear volume of the hepatic cells and coagulative necrosis in central areas ${ }^{7}$.

Thus, the hepatic effects produced by Equisetum arvense $L$. in rats seems be related to the dosage, being that our study which were used small doses of Equisetum arvense L. was not observed acute hepatoxicity of Equisetum arvense L. extract in rats. However, Semprini et al. ${ }^{7}$, shown that high doses of Equisetum arvense $L$. produced importants hepatic damages in rats. In contrast, Oh et al. ${ }^{8}$ observed that regular doses of Equisetum arvense $L$. produced hepatoprotective effect ${ }^{7,8}$. 


\section{Conclusion}

The data indicates that oral treatment with graded doses of Equisentum arvense L. was not able to produce significants hepatic changes when compared to the control group. Further studies are necessary to evaluate the chronic hepatotoxicity of Equisentum arvense $L$. in rats.

\section{References}

1. McCuskey RS. The hepatic microvascular system in health and its response to toxicants. Anat Rec. 2008;291(6):661-71.

2. Lee WM. Medical progress-drug-induced hepatotoxicity. N Engl J Med. 1995;333:1118-27.

3. Contreras JB, Poniachik JT, Planzer MD1. Drug induced liver disease: clinical and pathological patterns in 33 cases. Rev Med Chile. 2003;131:1128-34.

4. Black M. Acetaminophen hepatotoxicity. Gastroenterology. 1980;78:382-92.

5. Chitturi S, George J. Hepatotoxicity of commonly used drugs: nonsteroidal anti-inflammatory drugs, antihipertensives, antidiabetic agents, psycotropic drugs. Semin Liver Dis. 2002;22:195-206.
6. González Torres Y, Scull Campos I, Bada Barro AM, Navarro BG, Morales DF, Pérez MEA, Gómez ES, Sosa OH. Ensayo de toxicidad a dosis repetidas del extracto acuoso de Morinda royoc L. en ratas Cenp: SPRD. Rev Cuba Plantas Med. 2003;8(2):. Disponível em www.scielo.sld.cu.

7. Semprini M, Prado FO, Paz K, Regalo SCH, Lopes RA, Sala MAl. Hepatotoxicity of medicinal plants. Action of Equisetum Arvense. L. infusion in rats. Braz J Pharm Sci. 2003;39:217.

8. Oh H, Kim DH, Cho JH, Kim YC. Hepatoprotective and free radical scavenging activities of phenolic petrosins and flavonoids isolated from Equisetum arvense. J Ethnopharmacol. 2004;95(2-3):421-4.

9. Mimica-Dukic N, Simin N, Cvejic J, Jovin E, Orcic D, Bozin B. Phenolic compounds in field horsetail (Equisetum arvense L.) as natural antioxidants. Molecules. 2008;17:13(7):1455-64.

10. Arango HG, Mendes ST. Bioestatística: teórica e computacional. 2ed. Rio de Janeiro: Guanabara Koogan; 2005.

11. Toledo ACO, Hirata LL, Buffon MCM, Miguel MD, Miguel OG. Fitoterápicos: uma abordagem farmacotécnica. Rev Lecta. 2003;21(1):7-13. 12. Larrey D. Drug-induced liver diseases. J Hepatol. 2000;32(1):77-8.

\section{Acknowledgements}

The authors are grateful to the biologist Wanderley Nogueira Vilas Boas for his precious technical contribution.

\section{Correspondence:}

Nilo César do Vale Baracho

Rua Marechal Juarez Távora, 180

37502-106 Itajubá - MG Brazil

Phone: (55 35)3621-4610

nilocvbaracho@yahoo.com.br

\section{How to cite this article}

Baracho NCV, Vicente BBV, Arruda GAS, Sanches BCF, Brito J. Study of acute hepatotoxicity of Equisetum arvense L. in rats. Acta Cir Bras. [serial on the Internet] 2009 Nov-Dec;24(6). Available from URL: http://www.scielo.br/acb 